\title{
WHEN ABANGAN EMBRACES SUFISM: RELIGIOUS PHENOMENOLOGY TO COUNTER RADICALISM IN CONTEMPORARY JAVA
}

\author{
Amanah Nurish \\ University of Indonesia, Indonesia \\ E-mail: amanah11@ui.ac.id
}

\begin{abstract}
Abangan is one of the socio-religious groups regarded as a marginal community among the trichotomy of santri and priayi. It has been known that abangan were not religious Muslim, and they are poor farmers as well as workers, backward and less educated people. Meanwhile, santri are more religious and priayi among Javanese society are middle-class people practising syncretic Islam. The thesis on The Religion of Java, by Clifford Geertz, was more than a half-century indicated religious and social classification in Javanese society. In the midst of political polarization of Indonesian reformation, transnational Islamic groups began to establish their movement widely. Transnational Islamic groups that promote radicalism and violent extremism clearly avoid local wisdom and mysticism. As a result, abangan has experienced dramatic religious and social change. This study aims to see how to face radicalism after reformation in the social and religious transformation of abangan in Java. Previous studies have shown that the phenomenon of radicalism affects religious intolerance addressed to minority groups like abangan. This research paper aims to examine how abangan reacts to radicalism and engages with Sufism and their devotion to tarekat. Abangan recently appears to convert and join the tarekat movement as an alternative discourse to encounter modernism and religious radicalism.
\end{abstract}

Keywords: Abangan; Priayi; Islam; Tarekat Sufism; Radicalism.

Article history: Received: 21 January 2020 | Revised: 24 March 2021 Accapted: 14 May 2021 | Available online: 01 June 2021

\section{How to cite this article:}

Nurish, Amanah. "When Abangan Embraces Sufism: Religious Phenomenology to Counter Radicalism in Contemporary Java". Teosofi: Jurnal Tasawnf dan Pemikiran Islam 11, no. 1 (2021): 20-45. https://doi.org/10.15642/teosofi.2021.11.1.20-45. 


\section{Introduction}

The Religion in Java (1960) is always associated with the trichotomy of Santri, Priayi, and Abangan. ${ }^{1}$ Academic debates have culminated in these three social divisions of Muslim culture in Java. ${ }^{2}$ According to Hodgson, Geertz's studies on Santri, priyayi, and abangan "are religious social categories that were more likely to be influenced by the modernist Islamic viewpoint to categorize Javanese society." Hodgson also strongly argued with regard to the idea of polytheism in which Geertz shared his views on abangan, the category of Islam in Java. In the practice of Islamic Javanese (abangan), Geertz implicitly supported the modernist meaning of the word "shirk" when he categorized abangan. With regard to Javanese society's socio-religious group, it shows that Geertz's view on two groups of santri and abangan refers to "traditionalist" Muslim character, while priayi is more like Islamic syncretism, Hinduism, and kejawen, where religious rites and rituals are far from Islamic purification.

While priayi of the middle social group, they reside mostly in the Kauman areas around the palace castle. According to Ricklefs, the existence of abangan was first conceived in 1855 by a Dutch Christian, Hoezoo, who translated abangan as profane people. ${ }^{3}$ Abangan is also interpreted as people who keep slametan, but they do not receive 'slamet' because they do not perfectly practice normative Islamic teachings. Ricklefs' view of abangan was not only related to the Javanese Muslims but also to the Christians. According to Harthoorn, socio-religious phenomena emerging in response to the spread of Islamic revivalism are abangan and putiban or santri. ${ }^{4}$ This categorization was very politically charged because of the disparities between abangan and santri/putihan during the Dutch colonial era, which contributed to the separation of the social and economic classes in Javanese society.

1 Amanah Nurish, Agama Jawa: Setengah Abad Pasca-Clifford Geertz. (Yogyakarta: LKiS, 2019); Wilfred Cantwell Smith, "The Religion of Java," Economic Development and Cultural Change 11, no. 2 (1963): 203-206, http://www.jstor.org/stable /1152086\%5Cn; M.C. Ricklefs, "Rediscovering Islam in Javanese History," Studia Islamika 21, no. 3 (2014): 397-418. DOI: 10.15408/sdi.v21i3.1216.

2 Masdar Hilmy, "Islam and Javanese Acculturation: Textual and Contextual Analysis of the Slametan Ritual," (Theses: McGill University, Montreal, 1999), http:// search.proquest.com/docview/304560165? accountid=28431.

3 M.C. Ricklefs, "A History of Modern Indonesia since c.1200" (Creative Print \&

Design Ltd (Wales), Ebbw Vale, 2001), 480.

${ }^{4}$ Ibid. 
Ricklefs emphasized abangan vis-à-vis santri/putihan, in which the Dutch Christian missionaries, Heozoo and Ganswijk, misread both abangan and santri/putihan. Ricklefs also implicitly disagreed with the division of abangan and santri, as the Dutch missionaries who were around Semarang, Kediri, and Malang said in the 1800s. Javanese culture divided into the dichotomy of abangan and santri is typical to Javanese society at that time. ${ }^{5}$ The social groups of abangan and santri assisted the Dutch missionaries in provoking and segregating Javanese society for economic and political influence.

The binary opposition of santri and abangan today is important to the so-called Javanese society based on socio-religious and economic categories. ${ }^{6}$ In general, santri are usually identified with the merchant class, while abangan comes from the labour and peasant groups. 7 Santri is a social community that follows normative Islamic laws and teachings (regular prayer, hajj, zakat, etc.), ${ }^{8}$ while abangan are those who do not follow normative Islamic teachings like santri, but they practice slametan and tahlil, riarah, etc. The definitions of santri and abangan have changed since the political wave of Indonesian reformation. ${ }^{9}$ Burhani argued that the existing concept of abangan is not limited only to rural peasant communities but is commonly found in urban communities. In other words, abangan has changed in terms of context and social status.

During my fieldwork in Modjokuto, I found that abangan can be interpreted as a social and religious evolution ${ }^{10}$ that has randomly occurred between educated and middle-class people living in big cities and rural peasant communities. Abangan is no longer perceived as a non-religious culture, but today there has been a greater shift that abangan in Java is more interested in Tarekat and Sufism from Syech

\footnotetext{
${ }^{5}$ Ibid., 95.

${ }^{6}$ Robert B. Cruikshank, “Abangan, Santri, and Prijaji: A Critique," Journal of Southeast Asian Studies 3, no. 1, (March 1972); Zubair, "Abangan, Santri, Priyayi: Islam dan Politik Identitas Kebudayaan Jawa," Dialektika 9, no. 2 (2015).

7 Yogi Setya Prmana, "Kontestasi Abangan-Santri Pasca Orde Baru di Pedesaan Jawa," Jurnal Ilmu Sosial dan Ilmu Politik 14, no. 1 (2010).

8 Yon Machmudi, "The Emergence of New Santri in Indonesia," Journal of Indonesian Islam 2, no. 1 (2008).

9 Ahmad Najib Burhani, "Geertz's Trichotomy of Abangan, Santri, and Priyayi: Controversy and Continuity," Journal of Indonesian Islam 11, no. 2 (2017): 329, http://jiis.uinsby.ac.id/index.php/JIIs/article/view/556.

10 Robert N. Bellah, "Religious Evolution," American Sociological Review 29, no. 3 (1964).
} 
Siti Jenar. The current "secret text" can be interpreted as social, cultural, and political opposition to feudalism and authoritarianism in Javanese society's framework. Some religious figures in Pare say that abangan means followers of Sunan Kalijaga, Syech Siti Jenar, and their descendants. If we look at the religious traditions of abangan, they are related to Islamic mysticism or Sufism. ${ }^{11}$

After more than a half-century of Clifford Geertz's study on the "Religion of Java," the trichotomy of santri, priayi, and abangan is more complex in terms of meaning and religious practice, ${ }^{12}$ especially after the reformation, where Wahabism and Salafism have more space in Java. ${ }^{13}$ They are commonly referred to as militant groups that are antiabangan. Wahabism and Salafism in Java have become a common religious movement after Suharto's fall, and their da'wa is more militant in denying all local knowledge and culture, including abangan ritual and belief system in kejawen. ${ }^{14}$ Abangan has been struggling to confront Wahabism and Salafism groups rising widely through education and religious movement, and this phenomenon has made abangan closer to Tarekat and Sufism pesantren an alternative option for abangan to face the wave of radicalism that is increasing not only in Java but also in Indonesia as a whole. ${ }^{15}$ Therefore, the purpose of this research paper is to understand academically how abangan today tends to convert to tarekat movement and Sufism as an alternative type of

11 Sulistiyono Susilo and Ibnu Syato, "Common Identity Framework of Cultural Knowledge and Practices of Javanese Islam," Indonesian Journal of Islam and Muslim Societies 6, no. 2 (2016): 161, http://ijims.iainsalatiga.ac.id/index.php/ijims/article /view/587.

12 M.C. Ricklefs, "The Birth of the Abangan," Islam Zeitscbrift Für Geschichte Und Kultur Des Islamischen Orients 1, no. 1964 (2006): 35-55.

13 Rubaidi, "Variasi Gerakan Radikal Islam di Indonesia," Analisis: Jurnal Studi Keislaman 11, no. 1 (2011) https://doi.org/10.24042/ajsk.v11i1.607; Raudatul Ulum, "Salafi-Wahabi vs NU (Pertentangan Keberadaan STAI Ali Bin Abi Thalib di Semampir Surabaya)," Harmoni 15, no. 1 (2016) .

14 Kholid Karomi, "Tuhan dalam Mistik Islam Kejawen (Kajian Atas Pemikiran Raden Ngabehi Ranggawarsita)," KALIMAH 11, no. 2 (2013): 287-304 http://dx.doi.org/10.21111/klm.v11i2.97; Sulkhan Chakim, "Potret Islam Sinkretisme: Praktik Ritual Kejawen?," Jurnal KOMUNIKA 3, no. 1 (2011): 1-9.

15 Amanah Nurish, "The Myth of Religious 'Radicalism," Al-Albab 9, no. 1 (2020): 107-122 DOI: https://doi.org/10.24260/alalbab.v9i1.1546; Azyumardi Azra, "Islam in Southeast Asia: Tolerance and Radicalism," Miegunyah Public Lecture, 2005; Martin van Bruinessen, "Genealogies of Islamic Radicalism in Post-Suharto Indonesia," South East Asia Research 10, no. 2 (2002). https://doi.org/10.5367/ 000000002101297035. 
resistance to radicalism being a social, political, and religious challenge to religious freedom and pluralism in the Javanese context.

\section{Abangan and Mysticism in Anthropological Approach}

In his book entitled After the Fact (1995), Clifford Geertz explained that the majority of abangan were peasants and lowermiddle-class people living in rural villages in Java, and they often became political victims, including the tragedy of 1965 that killed thousands of abangan people Pare and Kediri. ${ }^{16}$ After mass killings in 1965, abangan had faced political battles with santri and had been economically marginalized during Suharto's rule. Abangan has always been related to supporters of the Indonesian Communist Party (PKI/Partai Komunis Indonesia), and this political stigma that has made abangan unlikely to become civil servants, soldiers, and government officials. Suharto has successfully swept away all the former supporters of the Indonesian Communist Party (PKI) linked to abangan and their generation.

Political catastrophe made Suharto's regime abolish the abangan in 1965. In his writing on "Where Have All the Abangan Gone" (2011), Robert Hefner stated that abangan is one of the most authentic variants of local Islam and is rooted in the cultural norms of Javanese society. According to Hefner, abangan has a tradition of Hinduism and Buddhism and has integrated Javanese values as a form of syncretic Islam. ${ }^{17}$ The tragedy of 1965 became a turning point in which the status of abangan deteriorated due to the New Order regime supporting a government program of socio-religious development.

"Three challenge prove to be particularly vexing for the abangan tradition: the spread of the Islamic boarding schools; the drawing up of santri-abangan tensions into party politics, especially in the 1950s and early 1960s; and state-supported to effort at social and religious "building up" from the 1970s on. The cumulative effect of these developments was that, by the 1980s, abanganism was in its last gasp". ${ }^{18}$

\footnotetext{
${ }^{16}$ Clifford Geertz, After The Fact: Two Countries Four Decades (Massachusetts: Harvard University Press, 1995).

17 Robert W. Hefner, "Where Have All the Abangan Gone," 2011.

18 Robert W. Hefner, "Where Have All the Abangan Gone?: Religionization and the Decline of Nonstandard Islam in Contemporary Indonesia," in The Politics of Religion in Indonesia: Syncretism, Orthodoxy, and Religious Contention in Java and Bali (London, New York: Routledge, 2011), 71-91.
} 
Santri and abangan faced a dramatic political clash in the 1970s, when santri, particularly from Muhammadiyah, were close to Suharto and held more government positions such as the ministry of religion and the ministry of education. ${ }^{19}$ At that time, the Indonesian government policy restricted public space for abangan. According to James L. Peacock, abangan greatly annoyed santris, who promote Islam's purity, and they were mainly Muhammadiyah. Abangan likes to blend Islam with indigenous cultures, such as grave pilgrimages, slametan ceremonies, and other cultural syncretic elements that blend with Islam. In fact, Islam's syncretism with the Javanese culture is still accepted by the traditionalist Santri (Nahdlatul Ulama/NU), but it is generally not accepted by the modernist Santri (Muhammadiyah). According to the Koran and the Hadith of the Prophet, modernist and reformist santri underscore Islamic teachings as the cornerstone of Islamic purification. However, according to them, the Holy Book does not justify the syncretism of Adat's religion. Therefore, the influence of animism, Hinduism, and Sufism must be eradicated from the lives of believers. ${ }^{20}$

"Purification of religious practice was necessary because of allthe non-Islamic mysticism, magic, animism, Hinduism, and Buddhism that had been incorporated into the Malay-Muslim syncretic "Islam", yet were not decreed by the holy text. Purifying through fundamentalism, the reformist sought to rediscover the original, the pure, the true Islam. Both ancient and contemporary, the faith was eternal, and with it, the believer could rationalize much of the modern world". ${ }^{21}$

Meanwhile, during his study in Modjokuto (Pare-Kediri), Robert Jay, a colleague of Clifford Geertz, states in his book 'Religion and Politics in Rural Central Java' that reformist Islamic groups from Arabia and Egypt had spread to Indonesia for several decades at the end of the 19th century. They are a reformist group upholding the purification of Islam.

"Reform in Islam had two aspects: the relation of Islam to the West and the relation of the faithful to the sources of Islam. The positions taken by the reformers varied greatly. Some

${ }^{19}$ Robert W. Hefner, "Islamizing Java? Religion and Politics in Rural East Java," The Journal of Asian Studies 46, no. 3 (1987): 533-554,.

${ }^{20}$ James L. Peacock, Purifying the Faith: The Muhammadijah Movement in Indonesian Islam (California: Cummings Publishing Company, 1978).

21 James L. Peacock, Muslim Puritans: Reformist Psychology in Southeast Asian Islam (California: University of California Press, 1978). 
insisted upon a return to the pure fundamentals of the Koran, undefiled by subsequent history, including contact with the West. The reform movement in Java, which took hold early in the twentieth century, espoused neither the extreme fundamentalism of the Wahabi movement in Syria and Arabia nor the extreme eclecticism of certain Indian reform movements." 22

Unlike Robert Jay's view ${ }^{23}$ that the Javanese community accepts syncretic Islam by seeing Muslim cultures in Java through structuralism, in addition to Walisongo, it is a kind of obedience to the Javanese monarchy. Mark Woodward takes a different view from Geertz and Robert Jay, who claims, through a symbolic approach, that the form of Islamic syncretism embraced by the abangan people is a trans-cultural religion so that its presence can be embraced in the local context of the Javanese.

"The mystical interpretations of Islam have served as paradigms for devotionalism, social order, and social life. Javanese religion must be understood in light of fields of meaning established by the larger Muslim tradition and raises questions concerning the mood of cultural analysis on which Geertz's account is based". ${ }^{24}$

Such trans-cultural language can be seen in the Javanese people's symbols and rituals, such as slametan, sekaten, and other forms of rituals that have often been associated with Islamic teachings. ${ }^{25}$ Mark Woodward confirms his argument that Islam with a local cultural style is a form of Islamic mysticism since Islam is not a static textual religion. Islam is a religion that is blended with local customs and culture. He has shown this in his anthropological research, except in Indonesia and Africa, where local Islamic traditions are similar.

\footnotetext{
${ }^{22}$ Robert Jay, Religion and Politics in Rural Central Java (New Haven: Yale University Press, 1963).

${ }^{23}$ M. A. Jaspan and Robert R. Jay, "Javanese Villagers: Social Relations in Rural Modjokuto.," Man 5, no. 2 (1970). https://doi.org/10.2307/2799709.

24 Mark R. Woodward, "The "Slametan": Textual Knowledge and Ritual Performance in Central Javanese Islam Source," The University of Chicago Press Journal 28, no. 1 (1988): 54-89; Mark R. Woodward, "Javanism, Islam and the Plurality of Ethnography," Anthropological Forum 6, no. 3 (1991): 339-363. https://doi.org/ 10.1080/00664677.1991.9967417.

25 Jochem van den Boogert, "The Role of Slametan in the Discourse on Javanese Islam," Indonesia and the Malay World 45, no. 133 (2017): 352-372; Suwito NS, "Slametan dalam Kosmologi Jawa: Proses Akulturasi Islam dengan Budaya Jawa," Jurnal Ibda 5, no. 1 (2007): 90-105.
} 
"Local Islams are determined not only by the qualities of local culture but also by the nature of the Essentialist materials that are the grist for the mill of local interpretation. The fact that Javanese-Received Islam was largely Sufi exerted a powerful influence on Javanese Local Islam's development. But Received Islam is far from static. It changes as the knowledge of the Essentialist corpus expands or contracts and as new works enter into the discourse of Essentialist Islam". ${ }^{26}$

Religious acculturation cannot be separated from the power element in the history of Javanese society. "Religion and Power"27 are the means of social integration for Javanese society. In the history of the Java religions, this can be proven during ancient Mataram and Majapahit, where Hinduism and Buddhism were the rulers' beliefs. During Demak's reign and the position of Walisongo, Islam was also a religion practised by the rulers, followed by the native community.

This historical fact indicates that religion and power are, in the context of Javanese culture, tangible sources of political, cultural, and social capital. This historical fact shows that religion and power are concrete sources of capital in the context of Javanese society in political relations, such as puppet shows, the worship of heirlooms such as keris, and other traditional types of art that are considered to contain the "money" element as a source of capital. ${ }^{28}$

"The Javanese tradition of political thought, therefore, typically emphasizes the signs of Power's concentration, not the demonstration of its exercise or use. These signs are looked for both in the person of the Power holder and in the society in which he wields his Power. The two are, of course, intimately related. In the words of one of Indonesia's most prominent contemporary intellectuals, "A central concept in the Javanese traditional view of life is the direct relationship between the

\footnotetext{
${ }^{26}$ Mark R. Woodward, Java, Indonesia, and Islam (London: Springer, 2011). 27 James A. Beckford, "Religion and Power," in In Gods We Trust: New Patterns of Religious Pluralism in America: Second Edition, 2017; Titus Hjelm, "Religion, Discourse and Power: A Contribution towards a Critical Sociology of Religion," Critical Sociology 40, no. 6 (2014). https://doi.org/10.1177/0896920513477664.

${ }^{28}$ Francis Fukuyama, "Social Capital, Civil Society and Development," Third World Quarterly 22, no. 1 (2001) https://doi.org/10.1080/713701144; Bradford Verter, "Spiritual Capital: Theorizing Religion with Bourdieu against Bourdieu," Sociological Theory 21, no. 1 (2003). https://doi.org/10.1111/1467-9558.00182.
} 
state of a person's inner self and his capacity to control the environment". 29

Contemporary anthropologists on Indonesian studies such as Martin van Bruinessen have conducted a number of studies on santri, tarekat, and sufism that have developed in Indonesia, including the phenomena of radicalism and extremism. After the collapse of the New Order regime, Suharto, Islam's face in Indonesia underwent dramatic changes. Transnational Islamic groups, jihadist movements, including violent extremism ties, have led Indonesia to conservatism. This has led to various kinds of religious conflicts and terrorism attacks in a variety of places, such as the Bali Bombing in 2002 and the various bombings in Jakarta.

"A more lasting development, however, appears to be the emergence of dynamic transnational Islamic movements that compete for influence with the older established Indonesian mainstream organizations, Muhammadiyah and Nahdlatul Ulama (NU), and make major contributions to setting the terms of the debate in Indonesia. Most significant among them are the Prosperous Welfare Party (PKS) and its affiliated associations, which constitute the Indonesian version of the Muslim Brotherhood, the Indonesian chapter of the Hizbut Tahrir Indonesia (HTI), and the apolitical Tablighi Jamaat and Salafi movements". 30

After the collapse of the New Order system, the face of Islam became more rigid and fundamentalist in Indonesia. As Robert Jay and Hefner have pointed out, Arab influence and the Salafi-Wahhabi ideology have contributed significantly to the growth of Islamic fundamentalism in Indonesia through schools and Islamic boarding schools. The 'Transnational Islamic Networks' mission in Indonesia is to purify Islamic teachings that are considered incompatible with alQur'ān and Hadīth. Muslims performing bid'ah and shirk rituals should be trained on a purer view of Islam. This has been a success among Muhammadiyah santri, but not among NU santris who still cherish local Javanese culture and traditions. Traditional pesantren in the NU circles are more welcome to the Sufism than modernist groups that promote reformist and Islamic purification. "The history

29 Soedjatmoko, "Indonesia: Problems and Opportunities," Australian Outlook 21 (December 1967): 266.

30 Martin van Bruinessen, Contemporary Developments in Indonesian Islam: Explaining the "Conservative Turn" (Singapore: ISEAS, 2013). 
of Islamic boarding schools is Sufistic and 'ubüdiyya. On the other hand, modernist Islam does not want to be constrained by the rigid structure of the Islamic schools and the Sufism of Abu Hāmid alGhazālī. They, the modernist Islam, are calling for the re-opening of the gates to ijtihad and social and political activities". ${ }^{31}$

Martin van Bruinessen argued that the teachings of Sufism in the past dominated South East Asia, including Indonesia. The key figures of Sufism include al-Ghazāî̄, Ibn 'Arabī and 'Abd al-Qādir alJīlāni. They are very influential among the traditionalist pesantren in Java in the teachings of Sufism and Tarekat. It seems that this Sufism and Tarekat attracted not only the attention of the traditionalist santri, but also of the abangan culture. According to Clifford Geertz, those who practice Hindu rituals seem far removed from the Islamic teachings among the modernist Islamic groups. "Ancestor worship and belief in spirits with redemption as the main form of ritual, occult and various types of mysticism that emphasize the union between God and man, ascetic practice in remote places: all this seems alien to Islam and closer to Hinduism or spiritualism. When viewed from the point of view of modernist Islam, abangan values and practices, it is certainly not in line with traditional Islam". ${ }^{32}$

After reviewing the above-mentioned literature review, it can be concluded that, along with the success of Islamization in Java, the values of local culture cannot be isolated from the syncretic form. ${ }^{33}$ Tarekat and Sufism embody these ideals in such a way that they are more commonly embraced by traditionalist santri and abangan communities. The issue of santri-abangan, who witnessed political struggle after 1965-1966, gradually marginalized the role of abangan, since they were considered a social group that supported Sukarno and the Indonesian Communist Party (PKI). In 1998 when Suharto fell, trans-national groups, such as Wahhabi and Salafi, formed religious political movements in Indonesia and led to violent extremism, which resulted in various acts of violence and religious intolerance.

The question is, how is the existing abangan? According to Hefner, abangan has declined statistically. There were signs in the field

31 Martin van Bruinessen, Kitab Kuning, Pesantren, dan Tarekat (Yogyakarta: Gading, 2012).

32 Ibid.

33 Andrew Beatty, "Adam and Eve and Vishnu: Syncretism in the Javanese Slametan," Royal Anthropological Institute of Great Britain 2, no. 2 (1996): 271-288. https://doi.org/10.2307/3034096. 
when I conducted ethnographic research in Pare (Modjokuto) that, in fact, the abangan people did not just disappear, but that some of them still retain the Javanese belief and some of them "convert" to sufism and study tarekat in pesantren (Islamic boarding schools).

\section{Sufism in Javanese Culture}

Pondok Pesantren is a religious educational institution that offers in-depth education and curriculum on Islam to the broader community's needs. ${ }^{34}$ Speaking of the Islamic Dawa through madrasah and pesantren, Kediri is one of the most well-known and influential centres for the growth of pesantren in Java. The Islamic education model in pesantren is the oldest educational model that succeeded in establishing the Islamic Da'wa in the archipelago. ${ }^{35}$ The number of pesantren in Kediri and Pare (Modjokuto) is very high, one of which is the Radlatul Ulum Islamic Boarding School, which teaches the Naqsabandiyya Order. The Tarekat is a Sufism organization under the leadership of the Shaykh/Guru/Murshid, which applies the teachings of Islamic mysticism. ${ }^{36}$ Tarekat is interpreted as an introduction to a sequence of Tasammuf teachings reaching a spiritual level, so one must go through the guidance of a teacher commonly referred to as Murshid. Tarekat can also be viewed as a way of achieving a degree of ma'rifah. Some theories suggest that Syekh Yusuf al-Makassari (16231699) was the first to implement and establish Tarekat in Indonesia. It is widespread, from Makassar, Kalimantan, Sumatra, Central Java to East Java. Meanwhile, the word Naqshabandiyya was first introduced by Muhammad b. Muḥammad Bahā' al-Dīn al-Uways al-Bukhārī alNaqshabandī, who was also the founder of the Naqshabandiyya

\footnotetext{
${ }^{34}$ Azyumardi Azra, Dina Afrianty, and Robert W. Hefner, "Pesantren and Madrasa: Muslim Schools and National Ideals in Indonesia," Schooling Islam: The Culture and Politics of Modern Muslim Education (2007): 172-198,

35 Joko Sayono, "Perkembangan Pesantren di Jawa Timur (1900-1942)," Bahasa dan Seni 1, no. sejarah pesantren (2005): 54-69; DM Herman, "Sejarah Pesantren di Indonesia," Al-Ta'dib 6 (2013); Syeh Hawib Hamzah et al., "Perkembangan Pesantren Di Indonesia (Era Orde Lama, Orde Baru, Reformasi)," Syamil 2, no. 21 (2014): 2339-1332.

36 Qoriah A. Siregar, "Tasawuf dan Tarekat (Dimensi Esoteris Ajaran Islam)," Jurnal Sosioteknologi 11, no. 27 (2012): 240-242, http://journals.itb.ac.id/index.php /sostek/article/view/1104/710; Martin Van Bruinessen, "The Origin and Development of Sufi Orders (Tarekat) in Southeast Asia," Studia Islamika 1, no. 1 (1994): 1-24.
} 
Order. He was born in 1318 in the village of Qasr-i-Hinduvan (later renamed Qasr-i Arifan) near Bukhārā, where he died in 1389. ${ }^{37}$

The character of Sunni Islam in Indonesia actively emphasizes the principles of mysticism found in Sufism, ${ }^{38}$ as can be seen from the Javanese community's religious traditions. The growth of Tarekat and Sufism itself is a narrative of Javanese society's long history in the development of traditional Islamic boarding schools. Sufism is embraced as a mystical movement by many different religious groups, ethnic groups, races, and social classes. ${ }^{39}$ Southeast Asian countries, such as Indonesia, have become a regional trajectory, from different backgrounds, of merchants and traders who influence each other, including the advent of Islam, embodied by Sufism's teachings. Ibn 'Arabî's notes have also stressed that in Sufism it helps one to see the world as a whole.

The essence of the propagation of Sufi teachings is to give priority to common wisdom principles by embracing other beliefs or sects for the sake of "love of God" and "peace with God". ${ }^{40}$ Because Sufism is a path to the goal of truth and unity of being, Sufism's teachings are not only limited to the Islamic principles in them but are also close to other teachings, such as Hinduism and Buddhism, as well as other systems of belief. "Union with God" is a fundamental concept which both Muslims and non-Muslims should follow. The idea that God resides in every creature implies the unity of humanity and the unity of all systems of belief. In tracing the roots of Sufism

${ }^{37}$ Marwan Salahudin, "Amalan Tarekat Qadiriyah wa Naqsabandiyah sebagai Proses Pendidikan Jiwa di Masjid Babul Muttaqin Desa Kradenan Jetis Ponorogo", Esoterik: Jurnal Akblak dan Tasawuf 2, no. 1 (2016), 65-79. DOI: http://dx.doi.org/ 10.21043/esoterik.v2i1.1619.

38 Vincent J. H. Hoube, "Southeast Asia and Islam", The Annals of the American Academy of Political and Social Science 558, no. 1 (2003): 701-729. https://doi.org/10.1177/0002716203588001010.

39 Azis A. Said and Nathan C. Funk, Toward Global Community: Sufism and World Order (London: Equinox Publishing, 2010).

40 Annemarie Schimmel, "Mystical Dimensions of Islam," Verfassung in Recht und Übersee 11, no. 4 (1978); Reynold A. Nicholson, The Mystics of Islam (London: Routledge, Kegan Paul, 1914), James A. Bellamy and J. Spencer Trimingham, "The Sufi Orders in Islam," Journal of the American Oriental Society 95, no. 1 (1975); Julia Day Howell, "Sufism and the Indonesian Islamic Revival," The Journal of Asian Studies 60, no. 3 (2001) https://doi.org/10.2307/2700107; A. J. Arberry, Sufism: An Account of the Mystics of Islam (London: Routledge, 2013); Din Wahid, "Sufism and the 'Modern' in Islam," Studia Islamika 10, no. 3 (2003). 
and its spread throughout the world, it is not appropriate to look only at the mystical practice to understand the reasons why it was adopted by people of various religions and cultures, even in Java.

In the archipelago, the entrance to Sufism has been active for many centuries via the Sumatra and Java trade routes. ${ }^{41}$ The first century of the Islamization of Southeast Asia coincided with the time of the emergence of medieval Sufism and the rise of the Tarekate societies, which later brought the Islamic style of Java closer to the doctrine of Sufism. ${ }^{42}$ The encounter between the Javanese teachings and the Terekat and the Sufism is also very similar to the teachings of the Walisongo, who succeeded in spreading Islam on Java's island. The fusion of local customs and culture is an undeniable tactic for the success of proclaiming Islam in Java. Walisongo is not a group of Javanese people, but they are able to adapt to Javanese culture in order to recognize their presence.

In his work on Sufism, Martin van Bruinessen mentions that one of the early Sufi legends, Ibrāhīm bin Adham, who lived in Hijriyah in the second century, had come from Persia to the Malayan Archipelago to spread Sufism. Ibrāhīm's family came from Balkh in Khurasan (now northern Afghanistan). The legend of Ibrāhīm and his teachings in the countries of Southeast Asia is very popular. As piety and devotion, Ibrāhīm's journey greatly inspired the propagation of Sufism in Sumatra and Java. In Southeast Asia, rulers are considered to be the most spiritually strong beings, the conduit between heaven and earth; they were God-humans, Shiva-Buddha, or bodhisattvas, before the advent of Islam, and after Islamization, many legitimized their status by claiming holiness. ${ }^{43}$

Elements of Indian Sufism mixed with Malaya's animistic beliefs are also very popular. Before Islam and Sufism came to Malaya, animism-Hinduism-Buddhism was very prominent in the belief and cultural mix of the people of South East Asia, including Java. One of the triumphs of Sufism was during the ancient Javanese empire, a synthesis of the local culture of the Malawi people.

41 Martin van Bruinessen, "Studies of Sufism and the Sufi Orders in Indonesia," Welt Des Islams 38, no. 2 (1998); Martin van Bruinessen, "Sufism, 'Popular' Islam and the Encounter with Modernity," in Islam and Modernity: Key Issues and Debates (Edinburgh: Edinburgh University Press, 2009).

42 Ibid.

43 Martin van Bruinessen, NU: Tradisi, Relasi-relasi Kuasa, Pencarian Wacana Baru (Yogyakarta: LKiS, 1994). 
Traditional values of belief and local culture are part of the gradual integration and approach of Sufism. Most of the Sufis character associations maintain close connections to local values and maintain this connection through generations. In this case, transnational religious movements often play a role in the creation of the diaspora through local symbolic forms and visions. According to Feener, the dominant flow of Sufism in the Southeast Asian region has two origins, the first being the elaboration of the Neoplatonic ideas of Ibn 'Arabī (12 $2^{\text {th }}$-century mysticism born in Spain) and secondly Sufism formulated by Imam al-Ghazālī (1058-1111). ${ }^{44}$

Indeed, studies of the Sufism network are more fertile in an archipelago country such as Indonesia, which has the largest Muslim population in the Southeast Asian region. Sufism itself, along with modernization, has developed. At the same time, some Muslim reformers have criticized the Sufi tradition for not being part of pure Islam. According to Howell, Sufis were accused of tolerating and providing space and loose attitudes towards local beliefs. They have shirk complexities, and they are opposed to Islamic law (Sharia). As a result of social and political changes in the period of the Islamic Revolution, Sufi organizations arose as a religious movement that was seen as touching urban society. ${ }^{45}$ With the Iranian revolution of 1979 , Sufi organizations are gradually being recognized as a new form of attention in Indonesia. The number of followers is growing, with a large number of followers. ${ }^{46}$ The growth of Sufism itself has not always been smooth. In Indonesia, for example, the Sufi movement has been questioned by other Islamic sects who argue that Sufism is not an element of pure Islamic teaching.

The Sufism discourse in Southeast Asia often refers to Indonesia, particularly Java, since Sufism is traditionally taught in Islamic boarding schools. The pesantren's central curriculum includes teachings of prominent Sufi clerics who teach "union with God" as a common ideal that both Muslims and non-Muslims should accept. ${ }^{47}$

\footnotetext{
${ }^{44}$ Michael Feener, "A Re-examiation of the Place of Al Hallajin: The Development of Southeast Asian Islam", Bridgen tot de Taal-Land-en Volkenkude 154, no. 4 (1998): 571-592.

45 Julia D. Howell, Sufism and The Modern in Islam: Modernity and Islamic Spirituality in Indonesia's New Sufi Network (London: IBTAURUS, 2007).

46 Bruinessen, "Studies of Sufism and the Sufi Orders in Indonesia."

47 Yudian Wahyudi, "Kuliah Umum: Sufisme", Universitas Islam Negeri Sunan Kalijaga, Yogyakarta (3 Juli, 2005).
} 
A Sufi who describes himself as a lover of God actively practices dhikr as a tool for connecting people with God. Of course, to love God as the creator of the universe is to first love all human beings, regardless of their religious affiliation.

"Sufism helps spread Islam in areas that are not conquered by an army. Sufism is a psychologically more appealing form of Islam. It is convincing not only in terms of religious experience but also in terms of philosophy. Also, Sufism has always been manifested in various forms of art, such as music, poetry, dance, and painting. These are spiritually and philosophically appealing features of Sufism led many elites to accept it and contribute more. Finally, through the artistic and intellectual efforts of these elites, Sufism crossed cultural and colonial borders with a broader reach". ${ }^{4}$

People we call "Sufis" even though they may not be members of a certain tarekat, are typically vigilant in attending recitations at Islamic boarding schools as well as joint prayer activities, like dbikr or wirid. ${ }^{49}$ In Indonesia today, the practice of Sufism is increasingly common not only among rural communities but also in urban areas. While Sufism has shaped Islamic civilization as well as the social and cultural circles of South East Asia, it faces a new context for its movement. ${ }^{50}$ Sufism invests not only in Islamic civilization in society but also as a mediator for the growth of technology, culture, connectivity, and personal relationships in the modern age of globalization. According to Carl W. Ernst, Sufism can be seen as commodification of faith in different formats in the global age. ${ }^{51}$ As a view and a life-principle, Sufism has an immense potential to make a meaningful contribution to the expansion of the interfaith dialog network and to the strengthening of connections between cultures that initiate peace in times of "crisis" like today. As a form of Islam, both individually and socially, Sufism can play an important role in

48 Saladdin Ahmed, "What Is Sufism?," Forum Philosophicum 13, no. 2 (2008). https://doi.org/10.5840/ forphil200813220

${ }^{49}$ Howell, "Sufism and the Indonesian Islamic Revival."

${ }^{50}$ Barbara Watson Andaya and Yoneo Ishii, "Religious Developments in Southeast Asia c. 1500-1800," in Nicholas Tarling (ed.), The Cambridge History of Southeast Asia, Vol. 1 (Cambridge: Cambridge University Press, 1998).

51 Kubilay Akman, "Sufism, Spirituality and Sustainability/Rethinking Islamic Mysticism through Contemporary Sociology," Comparative Islamic Studies 4, no. 1-2 (2008). DOI: https://doi.org/10.1558/cis.v4i4.1-4.2.1. 
fostering the dynamics of religion and the inclusiveness of syncretism at the cultural level. ${ }^{52}$

Talking about Sufism in Java would often have to do with tarekat classes. One of the well-known tarekat pesantren is Raudlatul Ulum, located in the Kencong-Pare (Modjokuto). Initially, this pesantren was built on the model and character of the salaf pesantren with the establishment of a classical Islamic curriculum. Raudlatul Ulum was founded in 1951 by KH. Sholhah, KH. Ahmadi, KH. Abdul Hadi and $\mathrm{KH}$. Zamrodji as pioneering figures. In addition to training and awareness activities on Islam, Raudlatul Ulum also organizes a number of skills and training programs. In the meantime, this training aims to equip students to explore and develop their interests and talents. The pesantren also holds business training in agriculture, animal husbandry, fisheries, carpentry, management, and cooperatives, which then became the backdrop to the relationship between the Terekat and the Sufism movements that formed Islamic boarding schools such as Raudlatul Ulum in Pare (Modjokuto).

Although the people around the pesantren were previously abangans, with the presence of the Raudlatul Ulum Islamic boarding school, the surrounding community has become more vigilant in the practice of worship. The influence of Raudlatul Ulum Islamic boarding school has its own interpretation of abangan Muslims who have been successfully "educated" to become santri through the heaviest media it manages. They themselves also clarified that, according to him, the word abangan was considered more important to see the Pare (Modjokuto) culture. The interpretation of abangan by the caretaker of Raudlatul Ulum Islamic boarding school is not as stated by Geertz, where the "abangan" people are said to be a group that does not practise Islamic law. In the background of the pesantren culture, abangan is actually a religious community that practices the principles of Sufism as taught by Syekh Siti Jenar about "manunggaling kawulo gusti". ${ }^{53}$

On the other hand, the abangan is present as a spiritual activator for the lower class society outside the priayi (upper class), and the term is derived from the words of the followers of Syekh Siti

52 Gauri Sharma, "Sufism: An Answer to Global Terrorism," International Journal of Interdisciplinary Social Sciences 5, no. 7 (2010): 223-230.

53 Interview with the caretaker of Raudlatul Ulum Islamic Boarding School, 25

November 2017. 
Jenar. The history and story of Syekh Siti Jenar himself is full of controversy because he is considered a "heretical" guardian. ${ }^{54}$ According to Hasanu Simon, Syekh Siti once studied with Sunan Ampel-he was regarded as a figure with great curiosity. After finishing his studies at Sunan Ampel, then Sheikh Siti Jenar settled in the Kediri. $^{55}$

At the beginning of its existence, the Raudlatul Ulum Islamic boarding school was not freely embraced by the local community. Although most of them were abangan, some were Hindus. As well as the improvement of the pesantren, which had more and more students, the surrounding neighborhood witnessed a tremendous metamorphosis from being predominantly Hindu and abangan. The majority of the community has now become santris. If we look at the changes in society in this field, important religious conversion from Hinduism to abangan and now to santri has taken place. One of this pesantren's achievements is the idea of tarekat teaching, and even this boarding school offers a place to study for hundreds of students between 50 and 70 years old. They are parents who live in pesantren to deepen their knowledge of tarekat and kitab kuning. Most of the santri are elderly women, widows, and retirees of different professional backgrounds, such as farmers, employees, teachers, and traders, who feel such a need to deepen Islam and the teachings of tarekat in old age. Most of the students who were abangan lived in pesantren to understand Islamic mysticism higher so that, when they die, they will become more peaceful and closer to God..$^{56}$

\section{Radicalism and Religious Bigotry}

The portrait of religious life in Java in particular and Indonesia in general has seen an extremely complex escalation; this was evident in the reform era of the fall of the new order regime. Trans-national Islamic groups have emerged, growing and expanding in Indonesia in

\footnotetext{
54 Frenky Icksan Nugraha, "Analisis Serat Suluk Syekh Siti Jenar," FON: Jurnal Pendidikan Babasa dan Sastra Indonesia 14, no. 1 (2019), DOI: https://doi.org/10.25134/fjpbsi.v14i1.2088; Aris Fauzan, “'Ingsun' Misteri Tasawuf Mistik Syekh Siti Jenar," Afkaruna 8, no. 2 (2012). https://doi.org/10.18196/aiijis.2012.0010.119-134.

55 Ahmad Muhlisin, Syekh Siti Jenar: Ajaran, Jalan Kematian dan Perjuangan Mengislamkan Tanah Jawa (Yogyakarta: Araska, 2015).

${ }^{56}$ Interview with Santri of Raudlatul Ulum, 25 November 2017.
} 
accordance with the growth of democratic government. ${ }^{57}$ Transnational Islamic movements such as HTI (Hizbut Tahrir Indonesia), MMI (Indonesian Mujahidin Council), Jamaah Tabligh, JI (Jamaah Islamiya), MIT (East Indonesian Mujahidin), Laskar Jihad, and so on, are an Islamist movement with characteristics typical with political views and anti-democratic governance. One of these organizations' features would be that they carry the doctrines of Islamic conservatism and fundamentalism and even deem for jihadism. Lately, groups like this have become identified as Islamic fundamentalist groups. ${ }^{58}$ According to Zuly Qodir, the trend of Islamic radicalism is a problem that emerges from socio-political, economic, historical, and psychological problems in society. Islamic radicalism is a political process that targets both Muslim and nonMuslim societies as a religious-political movement. Radicalism is not only an Islamic phenomenon but also a global phenomenon as a reaction to the rise of secularism and liberalism, which are perceived to be the creations of western politics. ${ }^{59}$

These radical Islamic groups did indeed exist during postindependence Indonesia, such as DI/TII, which battled against Sukarno's government, but the Suharto regime successfully banned these ideologies and organizations. After the New Order government's collapse under Suharto, radical Islamic groups in the post-reform era resorted to identifying theological doctrines with various types and movements. ${ }^{60}$ Under the background of Javanese society, these radical Islamic movements originated as reformist groups in the urban middle class and flourished among educated

57 Benny Baskara, "Islamic Puritanism Movements in Indonesia as Transnational Movements," DINIKA: Academic Journal of Islamic Studies 2, no. 1 (2017), DOI: 10.22515/dinika.v2i1.103; Mohamed Nawab Mohamed Osman, "The Transnational Network of Hizbut Tahrir Indonesia," South East Asia Research 18, no. 4 (2010), https://doi.org/10.5367/sear.2010.0018; Masdar Hilmy, "Akar-akar Transnasionalisme Islam Hizbut Tahrir Indonesia (HTI)," Islamica: Jurnal Studi Keislaman 6, no. 1 (2014), DOI: https://doi.org/10.15642/islamica.2011.6.1.1-13.

58 van Bruinessen, "Genealogies of Islamic Radicalism in Post-Suharto Indonesia."

59 Zuly Qodir, Radikalisme Agama di Indonesia (Yogyakarta: Pustaka Pelajar, 2014).

${ }^{60}$ Abd A’la, Genealogi Radikalisme Muslim Nusantara: Akar dan Karakteristik Pemikiran dan Gerakan Kaum Padri dalam Perspektif Hubungan Agama dan Politik (Surabaya, 2008); Ahmad Rizky Mardhatillah Umar, "Melacak Akar Radikalisme Islam di Indonesia," Jurnal Ilmu Sosial dan Ilmu Politik 14, No. 2 (2010) https://doi.org/10.22146/ jsp.10935; Amanah Nurish, "Muhammadiyah dan Arus Radikalisme," Maarif 15, no. 2 (2019): 59-74. 
people. Radical Islamic organizations have a new tendency to enter educational institutions, such as schools and universities. This radical Islamic group is much more widely accepted among urban and middle-class communities than that of rural abangan. The issue is, why then are radical Islamic groups more appropriate to urban people and the middle class than to abangans?

According to Durkheim's view of the theory of organic society and mechanical society, this could be a sociological analysis in which organic urban middle-class communities are more receptive to radical Islamic groups than abangan who live mostly in rural areas with mechanical characteristics. ${ }^{61}$ Second, the psychological factor may be one of the reasons why urban middle-class societies are more sensitive to radical Islamic groups because of the need to channel religious expressions that they are not channeled so that they can join radical Islamic organizations. Urban people who appear to be busy working or having everyday activities face psychological, economic, social, political, and cultural conflicts with their local environment so that they need space to express themselves as religious people. This is because religion plays an important role in every social, cultural, economic, and political life of Indonesian society.

Apart from the problems mentioned above, there is also the growth of radical Islamic viewpoints such as Salafi and Wahhabi in Indonesia, that are financed more by Saudi Arabia through a variety of aids, such as Islamic boarding schools and schools located in urban communities where the majority of the population is middle and upper class. After the Reformation, the development of new Islamic boarding schools and Islamic schools affiliated with Salafi and Wahhabi influenced the religious life in Java and led to the proliferation of radical Islamic movements. The concern is that when these radical Islamic groups carry out religious teachings towards teachers, university students and individuals who are part of their network, they provoke action and acts of intolerance against nonMuslim groups, such as the demolition of places of worship (churches) and even commit acts of anarchism towards sect Islam itself, such as the genocide of Ahmadiyah. Recent incidents of intolerance in Indonesia have been sparked by the increasingly fertile

61 Emile Durkheim, The Division of Labour in Society, ed. W.D. Halls (London: Macmillan Press, 1984); James A. Davis, "Structural Balance, Mechanical Solidarity, and Interpersonal Relations," American Journal of Sociology 68, no. 4 (1963). 
wave of religious radicalism. ${ }^{62}$ Recent studies by the Setara Institute have shown that intolerance, blasphemy, hate speech, denial includes the demolition of places of worship and other abuse of religious motivations. ${ }^{63}$

"Twenty-two violations of both the freedom of worship and belief have taken place. Seventy-two breaches concerning elected authorities as performers. The state actors who have committed the most abuses have been city officials, with 29 acts. Many state institutions who have also committed highprofile crimes have become the Police with 17 acts. Meanwhile, the three institutions in the list of other state actors that commit violations in the top six categories are educational institutions, with 8 acts." ${ }^{\circ 4}$

Wahhabi is one of the radical groups in Java that is antireligious pluralism. According to Singh and Qodir, the spread of Wahhabi in Java, such as Gresik, Kediri, Jombang, and Malang, like Central Java, such as Solo and Yogyakarta, is directed at modernist santris such as Muhammadiyah, but in recent times the spread of Wahhabi has also targeted rural areas in some traditionalist santri such as NU. ${ }^{65}$ At the same time, the Wahhabi movement has reached the countryside and spread in Yogyakarta, Solo, Jakarta, Makassar, and other major cities. The popularity of Wahhabi and Salafi's preaching among modernist santri is due to its similar characteristics, that of bringing pure Islamic teachings; anti-bid'ah, anti-pilgrimage to the grave (ziyara), and anti-slametan - these are all characteristics of abangan. The abangan genuinely possess local wisdom, which can only be accepted by the Tarekat and Sufism communities.

The expansion of transnational Islam in Indonesia and the strengthening of the issue of violent extremism after the reformation

62 Abdul Gaffar, "Jamaah Ahmadiyah Indonesia (JAI) dalam Perspektif Kekerasan Negara: Dua Kasus dari Surabaya Jawa Timur dan Lombok NTB," Jurnal Sosiologi Islam 3, no. 2 (2013): 28-50, http://jsi.uinsby.ac.id/index.php/jsi/article/view/37; Nina Mariani, "Ahmadiyah, Conflicts, and Violence in Contemporary Indonesia," Indonesian Journal of Islam and Muslim Societies 3, no. 1 (2013) https://doi.org/10.18326/ijims.v3i1.1-30; Muhammad As'ad, "Ahmadiyah and The Freedom of Religion in Indonesia," Journal of Indonesian Islam 18, no. 2 (2009) DOI: 10.15642/JIIS.2009.3.2.390-413.

63 https://setara-institute.org/melawan-intoleransi-di-tahun-politik/ (Accessed, October 13, 2020).

${ }^{64}$ Ibid.

65 Zuly Qodir and Bilveer Singh, Gerakan Islam Non Mainstream dan Kebangkitan Islam Politik di Indonesia (Yogyakarta: Pustaka Pelajar, 2015). 
also contributed to the division of Islamic communities. In response to the emergence of radicalism and terrorism, the tension among Muslims has indeed intensified. The identity of the Abangan people as Kejawen has started to be disrupted by the presence of militant Islamic terrorist groups displacing their tribal customs, which are in effect considered incompatible with Islamic values, which are rabmat li al-álamin. Aside from opposing the traditional forms and cultural heritage of the Javanese people, radical Islamic groups have also undermined the local culture and identity of the Javanese society in the form of religious practices for abangan Muslims who were not considered their rivals. The most concrete example is rejection larung (Javanese ritual and tradition living around coastal area and mostly they are kejawen or abangan) in Yogyakarta, disbanded by the FUI (Islamic Cultural Forum), a militant group that opposes the religious practices of abangan.

Apart from rejecting traditional forms and local culture of the Javanese people, radical Islamic groups also destroyed the local cultural identity of the Javanese community in the form of religious rituals for abangan Muslims who were not considered their enemies. The most concrete example is the dissolution of the larung ritual in Yogyakarta, which was disbanded by the Islamic Community Forum (FUI), a radical group that rejects the rituals of the abangan people. The breakdown of the larung rite, as in the case of Yogyakarta, is considered a form of da'wa. The practices performed by abangan are known to be idolatrous. ${ }^{66}$ Numerous forms of violence perpetrated by militant movements have resulted in religious strife. According to Hermann Haring, "religion appears to be aggressive when its existence is undermined." Various kinds of violence that have been committed by radical groups have resulted in religious conflicts. According to Hermann Haring, "religion tends to violence when its identity is threatened". Dissidents were the first to face the challenge of isolation, persecution, and abuse. When culture no longer allows violent aggression, the mechanism is resurrected and turned into psychological and social manipulation. ${ }^{67}$

\footnotetext{
66 https://www.benarnews.org/indonesian/berita/sultan-yogyalkecampembubaran -larung-laut-10152018151450.html (Accessed on October 13, 20 20). ${ }^{67}$ Hermann Haring, "Mengatasi Kekerasan atas Nama Agama (Kristen dan Islam)" in Beuken et.al., Agama sebagai Sumber Kekerasan (Yogyakarta: Pustaka Pelajar, 1997).
} 
The issue of abangan cannot be separated from either the matter of ethnic or religious identity. In this case, I use the concept of identity by Francois Houtart, stating that identity is a sense of belonging to a certain ethnic, national or social community which, in turn, provides social stability, status, a certain way of thinking, and daily actions as a form of culture. ${ }^{68}$ Abangan is not only a socioreligious category, as Geertz pointed out, but also a form of Javanese identity that continues the rituals and culture of their ancestors from generation to generation. That is why heterodox Islam among abangan is very powerful and opposes reformist and modernist Islam that are deemed indeed rigid and unfriendly to their local culture as their identity. Based on various phenomena and developments of radical Islamic groups, it can be concluded that their da'wa expansion uses violence. The history of the Salafism and Wahhabism movements in Indonesia, which are strongly committed to creating an Islamic State, has also left many traces of violent incidents in order to achieve political goals.

\section{Concluding Remarks}

After examining several hypotheses on the presence of abangan in Java, there are several signs of socio-religious and cultural shifts that have taken place in their midst. First, the Indonesian reformation opened up space for democracy in Indonesia and contributed to the growth of conservative Islamic movements such as Wahhabi, Salafi, and Hirbut Tabrir Indonesia (HTI), Indonesian Mujahidin Council (MMI), Jamaah Islamiyah (JI), and other extremist groups. Second, the political change of reformation in Indonesia has gradually raised religion's issue to public space in which the Muslim majority occupies greater political contestation. In this regard, radical groups misused democratic government to increase their da'wa. Radical groups that have arisen in the field of education, politics, and the media have increasingly affected religious attitudes of society, frequently leading to acts of bigotry and abuse of minority groups such as Shiah, Ahmadiyah, Christian, and abangan in the name of Islam. Third, the recent existence of religious division in Indonesia has not only caused socio-religious fragmentation in society but has also had an effect on

68 Francois Houtart, "Kultus Kekerasan atas Nama Agama", in Beuken, et.al., Agama sebagai Sumber Kekerasan (Yogyakarta: Pustaka Pelajar, 1997). 
the decline of local cultural values so that Javanese culture has gradually faded. After Indonesian reformation of more than two decades, followed by the growing of radicalism, abangan in Java are struggle to defend their tradition on kejawen as their belief system identity so that they need a container that can support the values of local spirituality that they believe. As a result, Tarekat and Sufism are an alternative choice for abangan in facing radical and extremist groups that very often threaten and eliminate abangan. This research paper concludes that the conversion of abangan to Sufism and their interest in tarekat is a religious phenomenology to resist religious radicalism in contemporary Java.

\section{Bibliography}

A'la, Abd. Genealogi Radikalisme Muslim Nusantara: Akar dan Karakteristik Pemikiran dan Gerakan Kaum Padri dalam Perspektif Hubungan Agama dan Politik. Surabaya, 2008.

Andaya, Barbara Watson and Ishii, Yoneo. "Religious Developments in Southeast Asia c. 1500-1800," in Nicholas Tarling (ed.), The Cambridge History of Southeast Asia, Vol. 1. Cambridge: Cambridge University Press, 1998.

Arberry, A. J. Sufism: An Account of the Mystics of Islam. London: Routledge, 2013.

As'ad, Muhammad. "Ahmadiyah and The Freedom of Religion in Indonesia," Journal of Indonesian Islam 18, no. 2, 2009, DOI: 10.15642/JIIS.2009.3.2.390-413.

Azra, Azyumardi. "Islam in Southeast Asia: Tolerance and Radicalism," Miegunyah Public Lecture, 2005.

Azra, Azyumardi., Afrianty, Dina., and Hefner, Robert W. "Pesantren and Madrasa: Muslim Schools and National Ideals in Indonesia," Schooling Islam: The Culture and Politics of Modern Muslim Education, 2007.

Baskara, Benny. "Islamic Puritanism Movements in Indonesia as Transnational Movements," DINIKA: Academic Journal of Islamic Studies 2, no. 1, 2017, DOI: 10.22515/dinika.v2i1.103.

Beatty, Andrew. "Adam and Eve and Vishnu: Syncretism in the Javanese Slametan," Royal Antbropological Institute of Great Britain 2, no. 2, 1996, https://doi.org/10.2307/3034096.

Bellamy, James A. and Trimingham, J. Spencer. "The Sufi Orders in Islam," Journal of the American Oriental Society 95, no. 1, 1975. 
Bruinessen, Martin van. "Genealogies of Islamic Radicalism in PostSuharto Indonesia," South East Asia Research 10, no. 2, 2002. https://doi.org/10.5367/000000002101297035.

Burhani, Ahmad Najib. "Geertz's Trichotomy of Abangan, Santri, and Priyayi: Controversy and Continuity," Journal of Indonesian Islam 11, no. 2, 2017, http://jiis.uinsby.ac.id/index.php /JIIs/article/view/556.

Davis, James A. "Structural Balance, Mechanical Solidarity, and Interpersonal Relations," American Journal of Sociology 68, no. 4, 1963.

Durkheim, Emile. The Division of Labour in Society, ed. W.D. Halls. London: Macmillan Press, 1984.

Fauzan, Aris. "Ingsun' Misteri Tasawuf Mistik Syekh Siti Jenar," Afkaruna 8, no. 2, 2012, https://doi.org/10.18196/aiijis. 2012.0010.119-134.

Fukuyama, Francis. "Social Capital, Civil Society and Development," Third World Quarterly 22, no. 1, 2001, https://doi.org/10.1080/ 713701144.

Gaffar, Abdul. "Jamaah Ahmadiyah Indonesia (JAI) dalam Perspektif Kekerasan Negara: Dua Kasus dari Surabaya Jawa Timur dan Lombok NTB," Jurnal Sosiologi Islam 3, no. 2, 2013, http://jsi.uinsby.ac.id/index.php/jsi/article/view/37;

Geertz, Clifford. After the Fact: Two Countries Four Decades. Massachusetts: Harvard University Press, 1995.

Haring, Hermann. "Mengatasi Kekerasan atas Nama Agama (Kristen dan Islam)" in Beuken et.al., Agama sebagai Sumber Kekerasan. Yogyakarta: Pustaka Pelajar, 1997.

Hilmy, Masdar. "Akar-akar Transnasionalisme Islam Hizbut Tahrir Indonesia (HTI)," Islamica: Jurnal Studi Keislaman 6, no. 1, 2014, DOI: https://doi.org/10.15642/islamica.2011.6.1.1-13.

Houtart, Francois. "Kultus Kekerasan atas Nama Agama", in Beuken, et.al., Agama sebagai Sumber Kekerasan. Yogyakarta: Pustaka Pelajar, 1997.

Howell, Julia Day. "Sufism and the Indonesian Islamic Revival," The Journal of Asian Studies 60, no. 3, 2001, https://doi.org/10.2307 /2700107.

Mariani, Nina. "Ahmadiyah, Conflicts, and Violence in Contemporary Indonesia," Indonesian Journal of Islam and Muslim Societies 3, no. 1, 2013, https://doi.org/10.18326/ijims.v3i1.1-30. 
Muhlisin, Ahmad. Syekh Siti Jenar: Ajaran, Jalan Kematian dan Perjuangan Mengislamkan Tanah Jawa. Yogyakarta: Araska, 2015.

Nicholson, Reynold A. The Mystics of Islam. London: Routledge, Kegan Paul, 1914.

Nugraha, Frenky Icksan. "Analisis Serat Suluk Syekh Siti Jenar," FON: Jurnal Pendidikan Bahasa dan Sastra Indonesia 14, no. 1, 2019, DOI: https://doi.org/10.25134/fjpbsi.v14i1.2088.

Nurish, Amanah. "Muhammadiyah dan Arus Radikalisme," Maarif 15, no. 2 (2019): 59-74.

----. "The Myth of Religious 'Radicalism," Al-Albab 9, no. 1, 2020. DOI: https://doi.org/10.24260/alalbab.v9i1.1546;

----. Agama Jawa: Setengah Abad Pasca-Clifford Geertz. Yogyakarta: LKiS, 2019.

Osman, Mohamed Nawab Mohamed. "The Transnational Network of Hizbut Tahrir Indonesia," South East Asia Research 18, no. 4, 2010, https://doi.org/10.5367/sear.2010.0018.

Qodir, Zuly. Radikalisme Agama di Indonesia. Yogyakarta: Pustaka Pelajar, 2014.

Qodir, Zuly and Singh, Bilveer. Gerakan Islam Non Mainstream dan Kebangkitan Islam Politik di Indonesia. Yogyakarta: Pustaka Pelajar, 2015.

Ricklefs, M.C. "Rediscovering Islam in Javanese History," Studia Islamika 21, no. 3, 2014, DOI: 10.15408/sdi.v21i3.1216.

Said, Azis A. and Funk, Nathan C. Toward Global Community: Sufism and World Order. London: Equinox Publishing, 2010.

Salahudin, Marwan. "Amalan Tarekat Qadiriyah wa Naqsabandiyah sebagai Proses Pendidikan Jiwa di Masjid Babul Muttaqin Desa Kradenan Jetis Ponorogo" Esoterik: Jurnal Akblak dan Tasawnf 2, no. $1,2016$.

Schimmel, Annemarie. "Mystical Dimensions of Islam," Verfassung in Recht und Übersee 11, no. 4, 1978.

Sharma, Gauri. "Sufism: An Answer to Global Terrorism," International Journal of Interdisciplinary Social Sciences 5, no. 7, 2010.

Smith, Wilfred Cantwell. "The Religion of Java," Economic Development and Cultural Change 11, no. 2, 1963, http://www.jstor.org/stable $/ 1152086 \% 5 \mathrm{Cn}$.

Umar, Ahmad Rizky Mardhatillah. "Melacak Akar Radikalisme Islam di Indonesia," Jurnal Imu Sosial dan Ilmu Politik 14, no. 2, 2010, https://doi.org/10.22146/jsp.10935. 
Verter, Bradford. "Spiritual Capital: Theorizing Religion with Bourdieu against Bourdieu," Sociological Theory 21, no. 1, 2003, https://doi.org/10.1111/1467-9558.00182.

Wahid, Din. "Sufism and the 'Modern' in Islam," Studia Islamika 10, no. 3, 2003. 